IRSH 48 (2003), pp. I67-202 DOI: I0.1017/S0020859003001007

(C) 2003 Internationaal Instituut voor Sociale Geschiedenis

\title{
Bolshevizing Communist Parties: The Algerian and South African Experiences*
}

\author{
AlLis ON DREW
}

Summary: In 1924 and 1925 the Comintern introduced its policy of Bolshevization. A goal of Bolshevization was the creation of mass-based communist parties. In settler societies this meant that the local communist party should aim to be demographically representative of the entire population. This article traces the efforts of the communist parties in Algeria and South Africa to indigenize, seeking to explain why their efforts had such diverse outcomes. It examines four variables: the patterns of working-class formation; the socialist tradition of each country; the relationship between the Comintern and the two communist parties; and the level of repression against communists in both societies. The cumulative weight of the variables in the Algerian case helps to explain why communist activity in the I920s - including the communist party's ability to indigenize - was far more difficult in Algeria than South Africa.

The establishment of the Communist International (Comintern), following the I9I7 Russian Revolution, inaugurated a period in which communism was promoted as a path of development that could be exported and implemented through a general, scientific model. This model, according to the Comintern, could be applied to all societies and was believed to be the one means of making an effective revolution. Yet, this general model was applied in a variety of social conditions and refracted through diverse perspectives. Although the apparent success of the Soviet revolution inevitably meant its dominance as a blueprint for socialist revolution, local communists interpreted Comintern and, more broadly, Marxist ideas in terms of their own traditions and experiences. ${ }^{\mathrm{I}}$ This article

\footnotetext{
* Research for this article was made possible by a grant from the British Academy, and I am very grateful to the Academy for its support. An earlier version of this paper was presented at the European Social Science History Conference, The Hague, 27 February-2 March 2002. I would like to thank René Gallissot, David Howell, and an anonymous referee for their comments. I. Taumo Saarela, "International and National in the Communist Movement", in Tauno Saarela and Kimmo Rentola (eds), Communism: National and International (Helsinki, 1998), pp. I 5-40, 19-20; for other perspectives on the relationship between the Comintern and its national sections see Mikhail Narinsky and Jürgen Rojahn (eds), Centre and Periphery: The History of the Comintern in the Light of New Documents (Amsterdam, 1996).
} 
addresses the question of why a general policy - that of Bolshevization propagated by the Comintern in I 924 and 1925 and, specifically, the goal of indigenization - had strikingly diverse consequences in two African settler societies, Algeria and South Africa. ${ }^{2}$

The policy of Bolshevization, unveiled at the Fifth Comintern Congress in June-July I 924 and revised by the Comintern's Executive Committee (ECCI) in March-April I925, concerned the organization of communist parties - or national sections - and their relationship to the Comintern. Following the Russian model, national sections were to be centralized and subjected to proletarian discipline; factions were no longer permitted. In addition to this reorganization, Bolshevization included other aims. ${ }^{3}$ One of these was the creation of mass-based communist parties. In settler societies this necessarily meant that the local communist party should aim to be demographically representative of the entire population. While the Communist Party of South Africa (CPSA) was successful in this goal of indigenization, becoming an overwhelmingly black organization by the end of the I920s, in Algeria, the Communist Party remained predominantly European in composition in the I920s and I930s. A standard explanation for the failure of indigenization in the Algerian case refers to the paternalistic and even racist attitudes of the numerically dominant European members. Yet, by comparison with the CPSA, it is difficult to sustain this argument. A comparative analysis shows that the difficulties in indigenizing faced by the Communist Party in Algeria were more complex than this claim suggests.

This article examines four variables across the Algerian and South African cases, any one of which might be a plausible explanatory factor. First, there is the political economy of each society, and specifically the patterns of working-class formation. Second, there is the socialist tradition of each country, out of which the respective communist movements developed. Third, there is the relationship between the Comintern and the national sections in question - the geopolitics of the international communist network. Finally, there is the political system, and particularly, the level of repression against communists in both societies during the period in which Bolshevization was launched. This comparative and

2. On communism in Algeria see, inter alia, Emmanuel Sivan, Communisme et Nationalisme en Algérie, 1920-1962 (Paris, I976); Henri Alleg, Jacques de Bonis, Henri J. Douzon, Jean Freire, and Pierre Haudiquet, La Guerre d'Algérie, vol. I (Paris, I98I), pp. I90-2 I 5; Danièle Joly, The French Communist Party and the Algerian War (Basingstoke [etc.], I99I). On communism in South Africa see, inter alia, Jack and Ray Simons, Class and Colour in South Africa I850-1950 [1969] (London, 1983); Sheridan Johns, Raising the Red Flag: The International Socialist League and the Communist Party of South Africa, I9I4-1932 (Bellville, I995); Allison Drew, Discordant Comrades: Identities and Loyalties on the South African Left (Aldershot, 2000).

3. Kevin McDermott, "Bolshevisation 'From Above' or 'From Below'? The Comintern and European Communism in the 1920s", in Saarela and Rentola, Communism: National and International, pp. 105-I I7, I 12. 
multivariable approach has implications for the study of the Comintern and its sections. Most discussions of the international communist network have been framed in terms of a centre-periphery model; debates have concerned the extent to which the Moscow-based Comintern dominated its sections. Consideration of a variety of possible causal factors, each of which could vary across a range of cases, indicates that such a problematic is far too simple to illuminate the complexities of communism as an international system.

\section{ALGERIA AND SOUTH AFRICA: POLITICAL CONTROL AND POLITICAL ECONOMY}

Algeria and South Africa display a number of striking similarities. Both countries were subjected to a protracted process of military conquest that resulted in the suppression of the indigenous people, the undermining of their social systems and the denigration of their cultures. Both countries were settler societies characterized by a striking national or ethnic divide socially, economically and politically - between the European settlers and the indigenous majorities. In both countries, the precolonial peasantry was subjected to a long process of proletarianization. As arable land was appropriated by Europeans, the land available to the indigenous people for cultivation and for grazing declined dramatically, leading first to sharecropping and then to the development of an agricultural proletariat and a migrant labour force. Rural Algerians moved first to cities in the late nineteenth century and then to France, while in South Africa, rural Africans became migrant workers on the mines and in towns. This process led, in both cases, to the formation of an urban working class that was rigidly divided along national or ethnic lines. ${ }^{4}$ Muslim Algerians and black South Africans were subjected to extreme social, economic, and political inequalities vis-à-vis their European and white counterparts. ${ }^{5}$

Nonetheless, the political systems and patterns of proletarianization of Algeria and South Africa differed in significant respects. In I 834, the French wrested control of Algeria from the Ottoman Empire, which had dominated it from the sixteenth century, and legally constituted it as part

4. See, inter alia, Robert Ross, A Concise History of South Africa (Cambridge, 1999), pp. 2 I53ff.; Charles-Robert Ageron, Modern Algeria: A History from 1830 to the Present (London, I99I), pp. 5-27, 65-67; John Ruedy, Modern Algeria: The Origins and Development of a Nation (Bloomington, IN [etc.], I992).

5. The terminology used to refer to different social groups in both Algeria and South Africa is a politicized issue. Here, I use the term "European" to refer to individuals of European origin living in Algeria, "Algerian" to refer to the indigenous Muslim majority, and "French" for those born in France or given French citizenship. In the case of South Africa, I use the term "white" to refer to all people of European origin or those so classified by the governments of the day. I use the term "black" to include all people subjected to racial discrimination. The terms "Africans", "coloureds", and "Indians" refer to the people officially classified as such. 
of France. The French government's policy aimed to unite European settlers, whatever their national origins, under the rubric of French citizenship. From I 865, North African Jews had the right to apply for French naturalization on an individual basis; the Crémieux decree of October I 870 gave French citizenship and equal rights to all North African Jews in Algeria. ${ }^{6}$ Muslims, by contrast, were subjected to a set of regulations known as the code de l'indigénat [Native Code], while government policy also divided the Arab and Berber Muslim populations through differential education and socialization. The code de l'indigénat remained in place until the Second World War. It aimed, according to Charles-Robert Ageron, to compel Algerians to strict obedience to the French regime. ${ }^{7}$ The code imposed extremely harsh punishments on Algerians for infractions that were not illegal in France but were unlawful in Algeria when committed by Algerians. These infractions included travelling without a permit, failure to pay special "native" taxes, defaming the French Republic, and speaking disrespectfully to or about a French official. The code de l'indigénat also meant that Algerians were not able to join the Communist Party. ${ }^{8}$

Efforts to reform the Algerian political system to allow greater Muslim representation date from the early twentieth century but were repeatedly met by resistance from European settlers. The reform movement gained momentum in 1907-1908 through the efforts of the Jeunes Algeriens. Styling themselves in opposition to the Vieux Turbans, the Jeunes Algériens idealized French culture and, in the years before the First World War, aspired to assimilation with France. The reform movement died down during the War, and postwar efforts at political reform, including the idea of common representation for both Europeans and Algerians, continued to meet with settler resistance. The Jonnart Law of 4 February 1919, which gave 43 per cent of the adult male Algerian population the right to vote in separate electoral colleges for those classified as non-French, conceded to settler concerns by dropping the idea of common representation for Europeans and Algerians. The maximum proportion of representation for Algerians was one-fourth in general councils and one-third in municipal councils. ${ }^{9}$ But the Jonnart reforms were strongly criticized by the Jeunes Algériens. This group gained a charismatic leader in the person of Emir Khaled - grandson of the

6. Ageron, Modern Algeria: A History, pp. I-I2; Charles-André Julien, Histoire de l'Algérie Contemporaine, vol. I, 3rd edn (Paris, 1986), pp. 2-105, 464-467.

7. Charles-Robert Ageron, Histoire de l'Algérie Contemporaine, vol. 2 (Paris, 1979), p. 24.

8. Ruedy, Modern Algeria: The Origins, p. 88; Janet Dorsch Zagoria, "The Rise and Fall of the Movement of Messali Hadj in Algeria, I924-1954", unpublished Ph.D. dissertation, (Columbia University, NY, 1973), p. 45 .

9. Ageron, Histoire de l'Algérie Contemporaine, pp. 227-253; Ruedy, Modern Algeria: The Origins, pp. I I0-I I 2, 91-92. 
anticolonialist Emir Abdel-Kader, who by the age of eighteen had declared, "Je suis Arabe and je veux rester Arabe". In i919, Khaled launched the influential bilingual newspaper L'Ikdam [Courage], in which the Jeunes Algériens attacked the reforms and the beni-oui-oui, or "yesmen", who supported the French politicians. ${ }^{10}$

In contrast to the very close relationship of Algeria and France, South Africa became effectively a politically autonomous union in I9ro. But this followed several centuries of European settlement and military conquest. The first European settlement in this part of Africa was established at the Cape in 1652 by the Dutch East India Company, leading to the destruction of the indigenous Khoisan pastoralist society. The British took control of the Cape Colony in I 806 , leading, by the I83os, to an exodus of Dutch settlers, or Afrikaners, north and east. The Afrikaners fought a series of wars over several decades against the indigenous African societies in the interior of the country and established political control. In I 843, Britain annexed Port Natal, wrested control of the region from Afrikaners and fought a series of military battles with the Zulus over many decades.

Rivalry between the British and Afrikaners was spurred by the mineral discoveries of the late nineteenth century, as was imperialist-fuelled industrialization. Diamonds were discovered in I 867 ; by i 870 there were an estimated I0,000 diamond diggers. Africans had traded in gold from the region for centuries; but in I886 Europeans "discovered" a seemingly endless gold supply at Langlaagte in the Transvaal. This precipitated the rapid development of the goldmining industry and further military struggles, culminating in the Anglo-Boer War of 1899-1902, in which Britain defeated the Afrikaner republics in the interior of the country. ${ }^{\text {II }}$

The year I9Io saw the launch of the Union of South Africa. Afrikaners and English-speaking whites remained sharply divided along ethnic lines, a legacy of the Anglo-Boer war, despite their political rights and privileges over blacks. The South African government strove, over the following decades, to bolster white dominance and to fragment the population along sectional lines. The black population was categorized as African, Coloured, and Indian. The minority of the black population that enjoyed a qualified franchise was systematically whittled away, while white men and, from I930, white women enjoyed the franchise and other democratic rights. Government proposals to eliminate black rights were differentially tailored for Africans, Coloureds, and Indians. Africans were subjected to pass laws, and their right to live in towns was progressively eroded and subjected to severe restrictions.

These racist laws did not go unchallenged. The year 1902 had seen the

Io. Quoted in Ageron, Histoire de l'Algérie Contemporaine, p. 240.

I I. Luli Callinicos, Gold and Workers, I886-1924 (Johannesburg, I98I), pp. 8-9. 
launch of the African Political Organization - later renamed the African People's Organization (APO). Its political identity was ambiguous. Calling for a qualified franchise for all men, regardless of colour, it nonetheless styled itself as "an organization of the coloured people only", with responsibility for "the rights and duties of the Coloured people [...] as distinguished from the native races". ${ }^{\mathrm{I} 2}$ The year I9I 2 saw the formation of the African political organization that transcended tribal identity - the South African Native National Congress, precursor to the African National Congress (ANC). Significantly, and in contrast to Algeria, despite the increasing strictures placed on political activity aimed at the extension of democratic rights, black South Africans were free to join those political parties that would allow them membership, including the Communist Party, until its banning in $1950 .^{\mathrm{I} 3}$

The quasicolonial status of Algeria, compared to South Africa's political autonomy, had implications for the respective communist parties. In Algeria, communists were members of the French Communist Party (Société Française de l'Internationale Communisme - SFIC) until i936, when an organizationally autonomous Algerian Communist Party was formed; the relationship of communists in Algeria to the Comintern was always mediated by the SFIC's Paris headquarters until I936. The French Communist Party has been historically consumed by the idea of the French nation, which was, in turn, shaped by the French Revolution; the Party could also point to the revolutionary legacy of the Paris Commune of I 87r. On the one side, this meant that the French Communist Party's relationship with the Comintern was characterized by tension, as it sought, not always successfully, to reconcile two revolutionary traditions. ${ }^{14}$ On the other side, within the French Communist Party, Algerian issues and concerns were repeatedly marginalized and subordinated to those of France and to the idea of the French nation. By contrast, the Communist Party of South Africa was founded in July I92 I as an autonomous party that affiliated directly to the Comintern, notwithstanding the Communist Party of Great Britain's occasional intervention, at the Comintern's behest, in the CPSA's affairs.

Moreover, the different patterns of proletarianization within the two countries had implications for working-class development and organization. French conquest of Algeria led to the seizure of fertile land from the indigenous people for the establishment of large farms and wine estates. By the start of twentieth century, many Algerians had lost their access to land and rural poverty was widespread. About 32 per cent of the rural

I2. Gavin Lewis, Between the Wire and the Wall: A History of South African "Coloured" Politics (Cape Town [etc.], I987), p. 57.

I3. Drew, Discordant Comrades, p. 200.

I4. Marc Lazar, "The French Communist Party between Nation and Internationalism", in Saarela and Rentola, Communism: National and International, pp. 4I-59, esp. 44-46. 
population were sharecroppers and about i 6 per cent were proletarianized. Although 48.6 per cent of the rural population still farmed their own land, the size and quality of land was insufficient for self-subsistence. This meant that many freeholders supplemented their income by labour on larger farms and by encouraging family members to work full-time or part-time in the labour force. By I9I4, wage labour was a characteristic feature of colonial agricultural production. The rural proletariat, comprising both Algerian and European workers, peaked in the I920s and I930s, then shrank with the mechanization of European agriculture and the slowing of agricultural production. ${ }^{15}$ The first years of the century also saw a small but accelerating movement of people to cities to work in small factories, workshops, and businesses, on docks, and in semiskilled and unskilled public sector jobs. By I905 these workers numbered about 50,000 . In I 830 about 5 per cent of the Algerian population lived in cities; before the First World War, this had risen to 8.5 per cent. ${ }^{16}$

Alongside the small movement to Algerian towns, migration to France began in the early twentieth century in response to French industrialization, and increased during the First World War, as young French men left for the war. Between 1907 and I9I 3 about 10,000 Kabyles responded to a call from French industries, in spite of protests from large landowners concerned about the difficulties of recruiting agricultural labourers. The emigrants, overwhelmingly young men whose families remained in Algeria, settled in ethnic communities within French cities. ${ }^{17}$ Algerian workers in France could earn about three to four times what they could in Algeria, enabling them to remit comparatively large sums to their families. By the end of I9I 8, official census counts estimated about 57,000 Algerians living in France. However, this was most likely an underestimation.

Bowing to pressure from large land-owners, or colons, concerned about labour shortages, the government attempted to stem the exodus. The Chautemps circular of is September 1924 imposed contractual conditions on Algerians travelling to France by third or fourth class. Although the Sarraut decree of 4 August 1926 confirmed the principle of freedom of travel, a further decree on 4 April 1928 imposed a financial fee of Fr.I 25 on those wishing to work in France. Yet, these measures failed to stop the flow of emigrants. Official government figures suggest about 69,000 Algerians in France in 1926, and 80,000 in 1928 . However, the figure is probably closer to 100,000: between I9I4 and I928 there were 47I,390 departures compared to 365,024 returns, suggesting that about 100,000 Algerians were living in France around $1928 .{ }^{18}$ Algerian workers who went to France not atypically remained in that far less oppressive

I5. Ruedy, Modern Algeria: The Origins, pp. 98-99, I 23.

16. Ibid., p. I25.

17. Ageron, Histoire de l'Algérie Contemporaine, p. 530.

I8. Ibid., pp. 527-529. 
environment. Many of them joined trade unions and had contact with the French Communist Party. Hence, Algeria was characterized by a displaced proletariat. As one commentator has put it, "l'Algérie est une société dont le proletariat est en France". ${ }^{19}$

South Africa also had a significant migrant labour population. But while Algerian workers migrated to France, African workers in South Africa migrated within their country, most often to work on mines. British capital had "discovered" South Africa's mineral riches before a significant proletariat existed; consequently, it had faced the crucial problem of securing, socializing, and disciplining a labour force. Following the mineral discoveries, both the colonial state and the capitalist class made various attempts to induce and coerce labour, using colonial law and taxation, as elsewhere in Africa. They settled on a policy of combining the colonial reserve system, in which African ownership and occupation of land was restricted to specified areas, with the use of migrant labour. The introduction of private property in the reserves accelerated proletarianization. The limitations on the size of land holdings stunted the growth of an African farming class in the reserves and at the same time led to loss of land holdings and to landlessness for many. By the early twentieth century poverty was pushing Africans into the migrant labour system. ${ }^{20}$ This process accelerated over the next several decades. By 1936, about I7 per cent of Africans in South Africa were urbanized; including Coloureds and Indians, the entire black South African population had an even higher degree of urbanization. In contrast, close to I 3 per cent of Algerians were urbanized.

The greater urbanization of South Africa's black population, compared to Algerians, and the different patterns of proletarianization, provide insight into the state of the working-class movement in these two countries. Black South Africans had a longer history of collective working-class activity, including strike activity, than Algerians. The I9 Ios was a decade of collective black working-class strike activity across South Africa, culminating in the 1920 black mineworkers' strike. This strike activity had a strong impact on a very small number of South African socialists who began to make initiatives towards black workers. More significantly, the formation of the Industrial and Commercial Workers' Union (ICU) in I 9 I 9 as a union of black dockworkers signalled the growth of a class-conscious black working class in the ports and, as the ICU developed into a mass movement that swept across the country, demonstrated the attraction of ideas of national liberation for blacks in both town

19. Pierre Bourdieu quoted in ibid., vol. 2, p. 526.

20. W.M. MacMillan, Africa Emergent: A Survey of Social, Political and Economic Trends in British Africa (Harmondsworth, I949), pp. I20-I 26. 
and countryside. By contrast, the first Algerian working-class organization that embraced ideas of national liberation, the Étoile Nord-africaine [North African Star], was founded by North African immigrants in Paris in the mid-I920s and only established itself in Algeria in the I930s. The differential patterns of proletarianization, urbanization, and of workingclass development in these two countries meant that the prospective social base from which the communist parties would first try to recruit indigenous members - the Algerian or black urban working class - was less developed in Algeria than in South Africa at a comparable period. A comparative examination of the first variable, the political economy and pattern of working-class formation in each society, suggests, accordingly, that the conditions for indigenization would have been more difficult in the Algerian case.

\section{SOUTH AFRICA'S EARLY SOCIALIST TRADITION AND THE FOUNDING OF THE CPSA}

The communist parties in Algeria and South Africa, formed at the start of the I920s, faced very different political and socio-economic contexts. In addition to their different organizational relationships with the communist parties of their imperial metropoles, communists in Algeria and South Africa had to come to terms with different socialist traditions. Indeed, early recruits to each party bore the legacies of these prior traditions. Although both parties adhered to the Comintern and came under its centralizing powers, the Comintern's ability to centralize and to standardize the policies and practices of its sections was circumscribed both by the diverse local contexts and by the different socialist traditions. Moreover, the Comintern's relationships with these local communists reflected the geopolitics of the international communist movement. In its early years, the Comintern's attentions were focused primarily on industrialized Europe, as the presumed base of international revolution, and secondarily on Asia. Within Europe, Germany received much attention; France, as a leading European power, was important, but its colonies were far less so. For the Comintern, both colonized and independent African countries were of low priority. ${ }^{21}$

The Comintern envisioned itself as the guiding force in an international revolutionary movement; the Soviet Union was its paradigm for a successful socialist revolution. At its Second Congress in July-August I920, the Comintern adopted Twenty-one Points that placed the Comintern at the centre of the international socialist struggle and 
stipulated the conditions for affiliation. ${ }^{22}$ The Comintern's activities were directed by the ECCI, whose composition reflected the disproportionate influence of the Russian Communist Party. The Twenty-one Points were premised on the idea that class struggle in Europe and North America was approaching civil war, an assumption already undermined by political developments at the time of their adoption. All national sections were expected to adhere to the Comintern's policies, and within each national section, factions were to be subordinated to the Central Committee. Democratic centralism meant that the Party centre was to have "complete power, authority and ample rights". Social-democratic and social-pacifist principles were to be replaced with communist ones. Reformists and centrists were to be removed from leadership posts in all labour organizations in favour of communists, even at the costs of replacing experienced with inexperienced personnel. Parties were to propagandize against the International Federation of Trade Unions - also known as the Amsterdam International - in support of a proposed Red International of labour unions. These points were the subject of intense debate by socialists around the world. ${ }^{23}$

However, between the Comintern's formation in I9I9 and its Second Congress in July I 920, it began to re-examine its position on "the national and colonial question". As the prospects of revolution in Europe waned, anticolonial and national liberation struggles were seen as means to weaken imperialism. A critical debate at the Second Congress concerned the significance of national liberation movements for socialism. Lenin and M.N. Roy of India were the main protagonists in the debate. Lenin argued that the Comintern should seek temporary alliances with bourgeois democratic movements in the colonies, while Roy stressed the difference between bourgeois democratic movements and movements of peasants and workers. Lenin conceded the politically ambivalent nature of bourgeois democratic movements and changed his position to one of support for national revolutionary, as opposed to bourgeois democratic, movements. ${ }^{24}$

The Comintern's requirements inevitably propelled changes in the organizational structure of socialist groups seeking affiliation. In South Africa, the tiny socialist movement was organizationally and ideologically eclectic, reflecting the diverse influences of the British, Eastern European, and American socialist traditions. The impact of the Comintern was to

22. "'The Twenty-one Points - Conditions of Admission to the Communist International' as Adopted at the Second Comintern Congress in 1920 and Appended to the Constitution of the Communist Party of South Africa by its Founding Conference in $192 \mathrm{I}$ ”, in Brian Bunting (ed.), South African Communists Speak, 1915-1980 (London, 1981), pp. 58-62.

23. Ibid., p. 60; McDermott and Agnew, The Comintern, pp. $225-226$.

24. Sheridan Johns, "The Comintern, South Africa and the Black Diaspora", Review of Politics, 37 (1975), pp. 200-234. 
initially inspire competition amongst the diverse South African groups for its recognition, while simultaneously pulling them towards unity. In South Africa, as elsewhere, the propulsion towards organizational unity was linked to a movement to marginalize those approaches not favoured by the Comintern.

South African socialists seem to have recognized the need for political equality for, and organization of, the oppressed majority a few years earlier than their Algerian counterparts. Whatever the differences amongst South African socialists on how to achieve revolution - through syndicalism, for instance, or political action - a common ground for many by the late igros was their opposition to the colour bar. Admittedly, aside from a handful, this did not take practical form. Galvanized by the emergence of collective black working-class protest, from the mid-igios a handful of socialists had begun organizing black activists, forming an organization called the Industrial Workers of Africa that was modelled on the Industrial Workers of the World. Hence, the veteran socialist and trade-unionist, Bill Andrews, could write to the English socialist and feminist, Sylvia Pankhurst, that two South African socialist groups, the International Socialist League and the Industrial Socialist League "clearly and fearlessly [stand] by the principle that no revolution can be successful without a recognition of the rights of the Native workers to full participation". ${ }^{25}$

Debates amongst South African socialists inspired by their desire to affiliate to the Comintern centred on the problem of centralization and the relative weight of political agitation versus syndicalist organization. In Cape Town, the Constitutional Socialist Society pulled out of unity talks objecting to the idea of a proletarian dictatorship, ${ }^{26}$ and in Durban the Social Democratic Party argued that the Twenty-one Points were antidemocratic. It believed that the requirement to break with all labour organizations that did not accept the Twenty-one Points would be divisive for the working-class movement. It felt that the Comintern's pressure for a speedy decision regarding affiliation, and its insistence on subordinating factions to central authority were antithetical to free thinking and discussion, and would mean "constant suspicion, distrust, strife, and the stifling of all personal generosity within any movement imbued with the spirit of the Third International". ${ }^{27}$

25. Letter from W.H. Andrews to Sylvia Pankhurst, I9 March I920, Russian State Archive of Socio-Political History (RGASPI), 495.64.I.

26. Sheridan Johns, "The Birth of the Communist Party of South Africa", The International Journal of African Historical Studies, 9 (1976), pp. 371-400, esp. 386-389; Gideon Shimoni, Jerws and Zionism: the South African Experience (1910-1967) (Cape Town, 1980), p. 175; E.A. Mantzaris, "The Promise of the Impossible Revolution: The Cape Town Industrial Socialist League, I918-192 I", Studies in the History of Cape Town, 4 (198I), pp. I45-173, I64.

27. Johns, "The Birth of the Communist Party", pp. 39I-393; Durban Social Democratic Party, "Socialist Unity in South Africa", The Communist Review, I: 4 (August I92I), pp. 73-76. 
The appeal of the Russian Revolution, and the belief that its success was a result of political action and, in consequence, could and should be replicated in other countries, ultimately prevailed amongst South African socialists. On 30 July I92 I, the CPSA (Section of the Communist International) was formed - after almost a year of discussion and planning involving more than ten groups. The Durban SDP remained outside, but constitutional amendments submitted at the conference, even if not carried, indicated that it was not alone in its concerns about centralization. Given the previously eclectic nature of the South African movement, acceptance of the Twenty-one Points was a large leap. In the absence of an organizationally embedded and strong socialist tradition, the delegates at the new party's launch represented the overwhelming majority of the country's socialists. But this was no more than 175 members out of a country of seven million, and there is no doubt that they felt themselves immeasurably strengthened through their relationship with the Comintern. ${ }^{28}$

Unity of the new party was seen as a necessary prelude to a greater unity - solidarity of the working class across colour lines. In June I920 Cape Town socialist, Manny Lopes, had written that in addition "to the task of fighting against the prejudices + ignorance of the masses (a task common to the Communists of all lands) we have this terrible task of combatting the widespread growth of race prejudice, nay even of race hatred". ${ }^{29}$ This view was amplified by Sam Barlin and David Ivon Jones, the two South African delegates to the Comintern's Third Congress, on the eve of the CPSA's founding. They were keenly aware of the limitations imposed by the new party's social composition. Most communists and sympathizers were members of white trade unions, and concerned to fight class collaboration in those organizations, they explained, and restrictive laws made it difficult for white communists to reach African workers. Barlin and Jones appealed to the Comintern to send a representative to South Africa to study the "Negro question and its relation to the Communist Party", and to provide financial assistance. "What is required", they argued, "is to assure economic sustenance to a few native workers as agitators and organisers [...] to organise their brothers. This primitive mass is waiting to be stirred." 30

28. Johns, "The Birth of the Communist Party", pp. 397-399; Drew, Discordant Comrades, p. 54 .

29. Letter from M. Lopes, Industrial Socialist League of South Africa to Dear Comrade, 24 June I920, RGASPI, Moscow, 495.64.I.

30. Memorandum to the Small Bureau of the Comintern on the situation in Africa from D. Ivon Jones and Sam Barlin, South African delegation to the Third Congress of the Communist International, I6 July I92 I, 3, RGASPI, 495.64.25. 


\section{FRENCH SOCIALISM AND THE EARLY YEARS OF COMMUNISM IN ALGERIA}

The socialist tradition in Algeria differed in marked respects from that of South Africa. Marx himself had spent a few months in Algeria - for health reasons - and Marx and Engels had written about the French conquest of Algeria. Their work certainly recognized the horrors of the conquest and the economic impact of colonization, although they did not consider its political or cultural implications for the oppressed majority. ${ }^{3 \mathrm{I}} \mathrm{How}-$ ever small it was, the socialist movement in Algeria reflected the established and intellectual French socialist tradition and, organizationally, the more centralized French model of the Socialist Party (Section Française de l'Internationale Ouvrière - SFIO), alongside a weaker anarchist tradition. ${ }^{32}$

An Algerian section of the French Socialist Party, reflecting the interests of organized - overwhelmingly European - workers, was officially launched in I 906. Its organ, Lutte Sociale, began in late I 907 as the organ of the Socialist Party in Oran; this was a French-language publication with an occasional article in Spanish, reflecting the significance of Spanish immigrants in Oran. The following January Lutte Sociale announced the first congress of the Fédération socialiste Algérienne, to be presided over by Marcel Cachin, a socialist professor of philosophy and a founding member of the SFIO, while he was on tour in Algeria. Cachin wrote about the need to address the misery of Algerian workers, and, over the years, articles in Lutte Sociale called for working-class unity across national lines. ${ }^{33}$ But generally the French Socialist Party gave very little attention to Algeria before I9I4. The leading French socialist, Jean Jaurès, saw the liberation of Algerians in terms of their gradual assimilation into the French polity, although the Socialist Party took no practical steps towards that goal before the war. ${ }^{34}$ Even in 1920 an article in the Socialist Party's French-based organ, Le Populaire, presented the exploitation of European workers as on a par with Jewish and Muslim workers, although another

31. René Gallissot, "Marx et l’Algérie”, Le Mouvement Social, 7I (April-June 1970), pp. 39-63; René Gallissot and Gilbert Badia (eds), Marx, Marxisme et Algérie (Paris, 1976), esp. pp. 383394; Mohamed Lakhdar Benhassine, "Le sejour de Karl Marx à Alger [...] du 20 Fevrier au 2 Mai I 882", in Alger: Lumières sur la Ville, Actes du Colloque (Algiers, 4-6 May 2002), pp. 71 3-729. 32. Charles-Robert Ageron, "Jaurès et les socialistes français devant la question algérienne (de I 895 à 1914)”, Le Mouvement Social, 42 (1963), pp. 3-27; Ahmed Koulakssis, Le Parti Socialiste et l'Afrique du Nord de Jaurès à Blum (Paris, 1991).

33. "Fédération Socialiste Algérienne", Lutte Sociale, no. 8, I9 (January I908) (with Lutte Sociale, I912, I919-1920, Bibliothèque National Française); Marcel Cachin, "Questions Algériens", Lutte Sociale, 7-I2 January 1912; Tiberius Gracchus, "Prolétaires Algériens unissons-nous!”, Lutte Sociale, 20 April i919; Koulakssis, Le Parti Socialiste, p. I24, cf. p. 3II, n. 6r.

34. Ageron, "Jaurès et les socialistes français", pp. 27-29. 
piece spoke out against the "odious" indigénat. ${ }^{35}$ However, in marked contrast to South Africa, French socialists could point to an indigenous French revolutionary tradition - both the democratic tradition symbolized by the French Revolution and the revolutionary and socialist tradition symbolized by the Paris Commune. With the formation of the French Communist Party, French communists could lay claim to both the French and the Bolshevik revolutionary heritages.

Communism in Algeria, as in South Africa, was born in seemingly auspicious circumstances. ${ }^{36}$ The First World War precipitated a growth in the working-class movement in urban Algeria, as it did in South Africa. Trade-union membership increased rapidly in these years, doubling in the Department of Alger and more than tripling in the Department of Oran. The workers' press, which had vanished during the war, revived between I91 8 and I920. In Algeria, the Socialist Party - out of whose ranks most communists would come - counted close to I,000 members in I 920 , before the founding of the French Communist Party. Individual socialists were prominent in the Ligue des Droits de l'Homme, which called for the greatest possible extension of Algerian representation both in local assemblies and in the Chamber of Deputies and the Senate. A wave of strikes and demonstrations in the springs of I9I9 and I 920 had raised the hopes of many socialists for the unity of Algerian and European workers, although it was clear that forging such unity would be far from easy. The presence of Algerian workers amongst the demonstrators inevitably sparked a wave of hysteria in the local press about a combined Bolshevik and Muslim threat. Despite this, the founding members of the Communist Party in Algeria were optimistic. In subsequent communist discourse, Jean-Louis Planche has noted, the strike waves of I9I9 and I920 became legendary. 37

In Algeria, however, discussion of the Twenty-one Points was much briefer than in South Africa. This was in part due to the earlier founding of the French Communist Party, launched in December 1920 at the Congress of Tours, precluding lengthy discussion beforehand. Not surprisingly, therefore, shortly after the Party's formation, critical but unresolved issues exploded into the open in Algeria. These concerned two of the Twenty-

35. Koulakssis, Le Parti Socialiste, pp. i 8 - i i 9.

36. Alexandre Juving, Le Socialisme en Algérie (Algiers, 1924), esp. pp. 258-277; CharlesRobert Ageron, "Les communistes français devant la question algérienne de I92 I à I924", Le Mouvement Social, 78 (1972), pp. 7-37, I I; Gilbert Meynier, L'Algérie Révélée: La guerre de 1914-19I8 et le premier quart du XX siècle (Geneva, I98I), esp. pp. 690-709; Ahmed Koulakssis and Gilbert Meynier, "Sur le mouvement ouvrier et les communistes d'Algérie au lendemain de la première guerre mondiale", Le Mouvement Social, I 30 (I985), pp. 3-32, 4-5.

37. Jean-Louis Planche, "L'internationalisme au feu des nationalismes: les communistes en Algérie (1920-1945)", in Abdeljelil Temimi (ed.), Mélanges Charles-Robert Ageron, vol. 2 (Zaghouan, I996), pp. 66I-688, 663. 
one Points, which were relevant to the Party's position on colonialism. The first was Point 8 , which read in part:

Every party desirous of belonging to the Third International should be bound to denounce without any reserve all methods of "its own" imperialists in the colonies, supporting, not only in words but practically, all movements of liberation in the colonies. It should demand the expulsion of its own imperialists from such colonies.

The other was Point I6, which insisted on a high degree of centralization but acknowledged that "the Communist International and the Executive Committee are, naturally, bound in every form of their activity to consider the variety of conditions under which the different parties have to work and struggle". ${ }^{8}$ The Twenty-one Points were first published in L'Humanité, the Paris-based organ of the French Communist Party, on 8 October 1920, and appeared in Lutte Sociale on I 8 November. The delegate representing Algeria at Tours, Charles-André Julien, a socialist regional councillor from Oran, had been instructed to discuss Points 8 and I 6 many aspiring communists in Algeria had expressed grave concern over them. But a telegram from the Comintern during the congress dominated the subsequent proceedings; discussion of the colonial question was abridged. Affiliation to the Comintern was therefore approved without thorough discussion of these two points. At the time, this did not cause undue concern for communists in Algeria: from their perspective, Point 8's stipulation of the expulsion of imperialists from the colonies was mediated by Point I6's recognition of local diversity. The mandates from Algeria representing entirely Europeans - overwhelmingly supported affiliation to the Comintern. At its foundation, the SFIC in Algeria was organized into three federations - of Algiers, Oran, and Constantine - reflecting the French government's division of the country into three administrative departments. ${ }^{39}$

By April I92 I, it was apparent that, for communists in Algeria, issues surrounding anticolonial struggle and social revolution were far from resolved. The views of Dr Louis Laurens, a medical doctor from Constantine and secretary of the local communist federation, were influential and far from unrepresentative. Laurens argued that a socialist France would facilitate Franco-Algerian cooperation and enable French

\footnotetext{
38. "The Twenty-one Points", in Bunting, South African Communists Speak, pp. 60-6I.

39. The Socialist Party's membership in Algeria was decimated. It appears to have been wiped out in Constantine; by 1924 the Algiers section had 375 members; see Koulakssis, Le Parti Socialiste, pp. I26-I28, I39, 312, nn. 71, 72; Ageron, "Les communistes français devant la question algérienne", p. I I; Koulakssis and Meynier, "Sur le mouvement ouvrier et les communistes d'Algérie", pp. 5-6; Jacques Choukron, "L'internationale communiste, le PC Français et l'Algérie (1920-1925)", Cabiers d'bistoire de l'Institut Maurice Thorez, 25-26, 2ème trimestre, pp. I33-I59, I36.
} 
civilization to play the educational role necessary for Algerian development. ${ }^{\circ}$ A similar view was reflected in a thesis put forward in April I92 I by the communist section of Sidi-bel-Abbes - a working-class town, known as the Red Mecca, that was located in the Department of Oran. Situated in the western part of the country across from Spain, Oran had a relatively high proportion of Spanish working-class immigrants. The Sidibel-Abbes thesis deprecated the role of indigenous elites, who were seen as representing a step backwards towards feudalism. It argued that a social revolution in Algeria was predicated on a prior socialist revolution in France, concluding that the Communist Party in Algeria should promote trade-union organization and communist propaganda, but should reject the "abandonment of the colonies" suggested by Point $8.4^{\mathrm{I}}$

But there were other emphases amongst local communists. ${ }^{42}$ Djerjeraoui - "a native communist" - argued that communism was the only doctrine able to satisfy Algerians' needs for equality. ${ }^{43}$ In I92 I, Victor Spielmann, a long-time radical who defended the cause of the small against the large and who belonged both to the SFIC and to Emir Khaled's Fraternité algérienne, launched a series on "la question indigène" in Lutte Sociale - now the organ of the local SFIC. The next year, Spielmann published a brochure on colonization and its impact on Algerians that Lutte Sociale urged all comrades to read. ${ }^{44}$ Nonetheless, in the early i 920 s the pages of Lutte Sociale were still clearly aimed at a European audience. With small print and no photos or illustrations, it required a high degree of French literacy. Its pages referred to the French and Russian revolutionary traditions and to issues concerning European workers; there was scant information on issues relating to colonial oppression or Algerian rights.

There were individual communists who were concerned about the French Communist Party's European orientation in Algeria. CharlesAndré Julien, who attended the Third Comintern Congress in June-July I92 I as the North African delegate, was a notable example. Both M.N. Roy and Julien criticized what they felt was the marginalization of colonial issues at the Third Congress. Julien was clearly aware of the obstacles to building communism in Algeria, not least of which was, as he put it, the

40. Louis Laurens, "Les aspects du socialisme en Algérie" (4), Lutte Sociale, 30 April I 92 I.

4I. "Ordre du jour voté par la Section socialiste (SFIC) de Sidi-Bel-Abbes dans sa reunion du 22 Avril I92 I", Lutte Sociale, 7 May I 92 I; Sivan, Communisme et Nationalisme en Algérie, pp. 2526; Koulakssis and Meynier, "Sur le mouvement ouvrier et les communistes d'Algérie", pp. 7-8; Ageron, "Les communistes français devant la question algérienne", p. I7.

42. Koulakssis and Meynier, "Sur le mouvement ouvrier et les communistes d'Algérie".

43. Djerjeraoui (Communiste indigène), "Le communisme et l'indigène”, Lutte Sociale, 7 January 1922.

44. "Études Algériennes", Lutte Sociale, i I March I922; Victor Spielmann, Colonisation et Question Indigène en Algérie en 1922 (Algiers, I922); "Victor Spielmann", in Dictionnaire Biographique du Mouvement ouvrier français, part 4, I914-I939, vol. 4I (Paris, 1992), pp. 403404 . 
scarcely disguised hostility of European communists in North Africa towards the indigenous majority. He insisted on the specificity of capitalist development in what he called the East, as opposed to the West. While capitalism had transformed social relations and led to the formation of an urban working class in Western countries, Julien contended, in the East capitalist development had produced agricultural workers rather than urban proletarians and left intact the privileged elites, whose interests lay with capitalism. The petite bourgeoisie or intellectuals were anticapitalist, however; accordingly, they had common interests with urban and rural workers. Communists needed to recognize that the struggle against imperialism included all these classes, he argued, and as aspirations for national independence had grown since the end of the War, the national question would be of first importance in the anti-imperialist struggle. In addition to engaging in purely communist activity, Julien concluded, communists must provide guidance to national liberation movements, while also pointing out to oppressed workers that their interests lay with communists rather than national elites. But Julien's views were very much in a minority amongst communists in Algeria. Significantly, his views were not endorsed by the other French delegates to the Congress; one of them pointedly dissociated the French delegation from Julien's intervention. ${ }^{45}$

In August I92 I, under the Comintern's influence, the French Communist Party established a Paris-based consultative body known as the Comité d'études coloniales. Its purpose was to study conditions in the colonized areas, with a view to creating movements against capitalism, militarism, and imperialism. ${ }^{4}$ This was headed by Paul Vaillant-Couturier, a supporter of Lenin's views on colonial liberation. In March I922, Vaillant-Couturier made a propaganda trip to Algeria, sweeping through nineteen cities, with twenty-three meetings in twenty-two days. Algeria, he wrote in Lutte Sociale, was a scandalous land, where imprisonment and political assassination were used against the indigenous masses by those who had stolen the country. 47 Yet, his paradigm assumed the primacy of revolution in Europe. The only security for the European population, he argued, was the education of the Algerian population in a North Africa liberated by international revolution; a victorious revolution in the metropole would lay the basis for a federated system of republics in North Africa. ${ }^{8}$ On

45. Charles-André Julien, H. Carrère d'Encausse, and M. Rebéroiux, "Les Communistes et l'Orient en 192 I", Le Mouvement Social, 82 (1973), pp. I06-I I3.

46. Comité d'études coloniales, "Projet de resolution sur le Communisme et les colonies", Lutte Sociale, 4 February I922, p. 4 . The committee was formally approved at the SFIC's congress in Marseilles in December.

47. P. Vaillant-Couturier, "Vive l'Algérie Révolutionnaire", Lutte Sociale, i April I922; Ageron, "Les communistes français devant la question algérienne", pp. 23-24, 29-30; Choukron, "L'internationale communiste", p. I46; Choukron dates the trip to February 1922.

48. P. Vaillant-Couturier, "Le problème indigène", Lutte Sociale, 4 March 1922. 
Vaillant-Couturier's return to Paris, he published a series of articles on "L'impérialisme français en Algérie" in L'Humanité, which in critical respects reflected the dominant point of view of the local Algerian communists. Under his direction, the Comité d'études coloniales evidently refrained from publishing the Comintern's Appel pour la libération de l'Algérie et de la Tunisie of 20 May 1922 so as to avoid putting undue pressure on the comrades in Algeria. It did, however, call for greater work amongst the Algerian population, and for the publication of political tracts in Arabic. But this stance did not satisfy the Algerian federations, which felt that Paris did not take their perspectives sufficiently into account. ${ }^{49}$

The Algerian sections opposed the Comintern's call for liberation in North Africa. The Sidi-bel-Abbes section argued that diverse colonial conditions negated the viability of a single thesis on the colonial question; that only local communist federations were qualified to develop local communist tactics; and that the Algerian sections would not agree to disseminate propaganda material relevant to their situation that they had not had the opportunity to see and approve. It maintained that a Muslim revolution would entail a return to feudalism, that revolution in France was a precondition for national emancipation in Algeria, and, accordingly, that propaganda aimed directly at Algerians would backfire. Similar views were voiced at the second interfederal Congress of North Africa on 24 September 1922, which rejected the Comintern's general propositions in the name of local specificities, and concluded that it was impossible to build a national liberation movement in Algeria at that point. ${ }^{50}$

There was, nonetheless, some Algerian interest in the Party's activities. A communist antiwar demonstration on 2I May 1922 drew about 300-400 people, including many young people, a few women, and about 50 Arabs, reported the British Consul-General in Algiers. ${ }^{\text {I }}$ Lutte Sociale published occasional articles on the need to reach Algerian workers. A piece by trade-unionist, A. Boye, urged European workers to "think of our native comrade as a brother [...] more unhappy than us because he carries the marks of long years of oppression", and as "a victim of our common enemy: international capitalism". ${ }^{2}$ Similarly, Victor Spielmann continued his columns on the "native question". Nonetheless, such efforts remained in the minority.

With international socialism clearly in retreat, the main issues at the Fourth Comintern Congress in November-December 1922 were "im-

49. Ageron, "Les communistes français devant la question algérienne", pp. 26-28, 27.

50. Ibid., pp. 29-30; Koulakssis and Meynier, "Sur le mouvement ouvrier et les communistes d'Algérie", p. 6; Choukron, "L’internationale communiste", p. I37.

51. Report from Consul-General Cave (Algiers), 22 May i922, FO 37I/827I [W 4486], Public Record Office, London.

52. A. Boye, Secrétaire, Pour la CA de l'UDUA, "Vie syndicale: L'ouvrier indigène", Lutte Sociale, is September 1922. 
mediate demands" and "united fronts"; the Comintern also placed greater emphasis on the national and colonial question, as well as the struggle for black liberation. Not surprisingly the SFIC's failure to promote Point 8 roused the Comintern's criticism. Leon Trotsky played a central role in the relationship between the Comintern and the SFIC; at the Fourth Congress Trotsky castigated the Sidi-bel-Abbes thesis as representing the mentality of slave owners. The repudiation evidently caused shock waves amongst the local communists. In December i 922, Maxime Guillon, Secretary of the Sidi-bel-Abbes region, and of the Algerian interfederation, and author of the Sidi-bel-Abbes thesis, resigned from the Communist Party; a spate of resignations followed in the Oran region. ${ }^{53}$ Party membership dropped to about 530, about half what it had been at its foundation. ${ }^{54}$ The transition was marked by the departure of intellectuals and members of the liberal professions from the leadership of the local party: Maxime Guillon and Charles-André Julien of Oran, both teachers, and Dr Louis Laurens of Constantine. The regional balance of power shifted as Oran lost its status in the interfederation. Étienne Mazoyer, an Algiers railway worker, took over leadership of the interfederation, symbolizing the growing dominance of the region of Algiers and of workers. Concerned to follow the Comintern, Mazoyer promised greater attention to the colonial question and to Algerian recruitment. New names became prominent in the pages of Lutte Sociale.5s

The next two years saw greater attention to Algerian issues. In 1922, Lutte Sociale's pages were still ambivalent about the value of a national movement, and apparently racist pleasantries could be found. ${ }^{6}$ An article by a certain Mekloub exhorted young Algerians to leave their national associations and join workers' organizations, the only places, he contended, where men opposed to all forms of international exploitation could be found. 57 But the next year saw somewhat greater concern with

53. Ageron, Modern Algeria: A History, p. 380; Sivan, Communisme et Nationalisme en Algérie, pp. 28-30; Koulakssis and Meynier, "Sur le mouvement ouvrier et les communistes d'Algérie", p. 16.

54. According to Choukron, "L'internationale communiste", p. I46, Algiers had 350 members, of whom 250 had 8 stamps on their card, Oran had I00 members with 8 stamps, and Constantine 80 with 8 stamps. Thus there were about 430 members in all who paid dues regularly, indicating a serious loss of members - of about half since 1920.

55. Koulakssis and Meynier, "Sur le mouvement ouvrier et les communistes d'Algérie", pp. 2 I23 , suggest that as those with a trade-union background replaced the first generation of intellectual leaders, their concern with rebuilding working-class unity across national lines after the set-backs of I92 I coincided with the desire to improve their profile in the Comintern's eyes. 56. For example, "Le carnet de Kaddour", Lutte Sociale, io April 1922. Kaddour purported to be the "native editor" of Lutte Sociale, writing in a barely comprehensible French, possibly reflecting a French stereotype about who could speak the French language.

57. Mekloub, "Pour développer le Communisme en Algérie", Lutte Sociale, 2 I April 1922. 
Algerian rights..$^{8}$ Lutte Sociale published more articles on local conditions, such as rural famine, and issues relevant to the Algerian population, such as the indigénat. 59 From I 6 November 1923, the paper's sub-title became Journal Communiste Algérien, and it ran the slogan "workers of all lands unite" in both French and Arabic. It advertised initiatives such as the Comité Algérie de secours aux indigènes [Algerian Committee for Aid to Natives], launched in February 1923 by Drs Belqacem Benthami and Abdennour Tamzali, both leading members of the Jeunes Algériens, and of which communist Victor Spielmann was Treasurer-General. January I 924 saw the launch of the Cercle Franco-Indigène Nord-Africain - the idea for which had first been mooted in I92 I. Organized by Victor Spielmann and $\mathrm{Dji}$ Taleb, it aimed at a rapprochement of Europeans and Algerians and for a gradual extension of Algerian rights - "while safeguarding and consolidating the development of French influence"!60 The year I 924 also saw the publication of a pamphlet called the $A B C$ du syndicalisme [ABC of trade unionism], by R.A. Crémieux and dedicated to Étienne Mazoyer. Crémieux was scathingly critical of racist sentiments - both anti-Semitism and anti-Algerian racism - amongst European workers. To those European workers who argued that "Le syndicalisme est bon, mais pas pour les indigènes!”, Crémieux retorted: "Travailleurs de tous pays, unissez-vous [...]. Même et surtout, les indigènes!” This was a clear indication that by I924 some communists, even if a minority, were concerned to organize workers in Algeria into a movement embracing both Europeans and Algerians. ${ }^{6 \mathrm{I}}$

The Comintern's intervention regarding the allegedly slave-owning mentality of European communists in Algeria reflected its own dynamics with the French Communist Party - notably its belief that the SFIC was slow in following its directives. That the Comintern did not intervene over this issue in the CPSA at that time did not mean that such attitudes were absent in the South African section. The Sidi-bel-Abbès episode has coloured subsequent historical interpretations of the Communist Party in Algeria. Its failure to grow and to indigenize for many years has been attributed largely to the supposed slave-owning mentality of the early

58. Ali Abdulhak, delegue au 4ième Congres de l'Internationale, "Aux travailleurs d'Algérie", Lutte Sociale, 6 April 1923.

59. Lutte Sociale, 6 April and 26 October 1923. An article on the condition of women in the Muslim republics of the Soviet Union reflected some interest in thinking about issues relating to Muslim societies; but another piece on votes for women sought the vote on the same basis as men, not discussing the implications of this for Algerians or indeed making any mention of Muslim women. Joseph Castagne, "La condition de la femme dans les républiques Soviétiques Musulmanes”, Lutte Sociale, I 3 April I923; Lucie Colliard, "Le votes des femmes”, Lutte Sociale, 26 October 1923.

60. "Un cercle franco-indigène Nord-africain", Lutte Sociale, i I January I924, transl. from the French; Sivan, Communisme et Nationalisme en Algérie, pp. 32-34.

61. R.A. Crémieux, $A B C$ of Syndicalisme (Algiers, 1924), esp. pp. 24-30 and quote 30. 
communists. ${ }^{62}$ Many, if not most, of these early communists may well have had patronizing and racist attitudes towards the Algerian majority. Yet, even after the Sidi-bel-Abbes thesis had been officially rejected, its proponents marginalized, and greater attention placed on the recruitment of Algerians, the Party had great difficulties in recruiting an Algerian membership. By late I925 Algerians numbered approximately 3 Io out of I, 540 members, or about 25 per cent of the total; this figure was higher than in the following years. A report of January 1927 indicated that before the Congress of Lille the Party had had 80 Muslim members but that they had since left. ${ }^{63}$ By contrast, while the CPSA had only one African member up to 1925 , by 1928 it claimed about I,600 African members out of approximately $1,750.64$ The differential experiences of the communist parties in Algeria and South Africa with regard to indigenization cannot be explained solely by the racial or nationalist attitudes of local communists.

\section{THE CPSA, BOLSHEVIZATION, AND THE TURN TO BLACK LABOUR}

The Comintern introduced the Bolshevization policy at its Fifth Congress in 1924; the ECCI amended it the following year. The policy was a reaction to the defeat of the attempted German revolution in 1923, a defeat that compelled Bolsheviks to reassess their thinking on the prospects of further social revolution in Europe and across the world. It also reflected the ongoing power struggles in the Russian Communist Party between the Zinoviev-Kamenev-Stalin triumvirate, on the one side, and Leon Trotsky, on the other. Led by Zinoviev, the ECCI decided that the fiasco in Germany was due to a "right deviationist" leadership that had been soft on social democracy - and to which failure the triumvirate strove to link Trotsky. Bolshevization was an attempted left turn to counteract the

62. Sivan, Communisme et Nationalisme en Algérie, pp. I3-36. But Koulakssis and Meynier, "Sur le mouvement ouvrier et les communistes d'Algérie", pp. 26-27, and Planche, "L'internationalisme au feu des nationalismes, p. 664, have situated the Sidi-bel-Abbes thesis against the backdrop of the I92 I famine. The famine, particularly severe in Oran, where Sidi-belAbbes was located, drove peasants into towns, where they were squeezed into overcrowded camps that became fertile zones for a typhus epidemic. The ensuing panic may have dampened any possibility of working-class solidarity and intensified racism. Koulakssis and Meynier, "Sur le mouvement ouvrier et les communistes d'Algérie", p. 32, argue that the views expressed by local communists in the early i920s were less uniform than has been previously presented, that support for the Sidi-bel-Abbes thesis was not unanimous, and that the rise of a new leadership seeking to build working-class unity across national lines preceded the Comintern's intervention.

63. P. Biboulet, Region Communiste d'Algérie, I7 October I925, typed ms, Archives du Parti Communiste Français (PCF), microfilm, file I72; Procès-verbal de la réunion de la Commission Colonial Centrale, i7 January 1927, PCF file 24I.

64. Drew, Discordant Comrades, p. 77. 
alleged right deviation. The ECCI argued that successful revolution was premised on the national sections applying the, ostensibly successful, Bolshevik model to their own situation. Ironically, the failure of revolution in Germany, by confirming Russian isolation, gave greater credibility to the Soviet experience. The Bolshevization policy, therefore, reflected the growing hegemony of the Russian Communist Party within the Comintern. ${ }^{65}$

The Fifth Comintern Congress mandated that a Bolshevized party "must be a real mass party", and "must be a centralized party, permitting no fractions, tendencies or groups" ${ }^{66}$ In the ECCI's words, Bolshevization meant "the application of the general principles of Leninism to the concrete situation of the given country". Necessitating "iron party discipline", it was "a permanent and continuing process", which had only just begun "in the best European parties of the Comintern". ${ }^{67}$ The old style of social-democratic organization, in which a few branch members did the work while the majority were inactive, was deemed unacceptable. A Bolshevik party was to be governed by a Central Committee. The line of command was to run from the Central Committee to district committees and then to local groups. Communists in trade unions and similar bodies were to form fractions to advance party policy and to win elections to official posts. Party members within a specific workplace were required to form a nucleus and act under party discipline. The accent on building a "mass party" had particular implications for communist parties in settler societies where the working class was divided along ethnic lines. In such cases, communist parties were actively to recruit members from the oppressed sections of the local population, so that the Party would be demographically representative of the entire population, and not simply reflect the interests of the more privileged stratum of the workforce. In other words, the recruitment of workers across ethnic lines was a logical consequence of Bolshevization.

Until the mid-I920s, the CPSA's position on black workers was ambiguous. Trade-union organization dated from the late nineteenth century, as white workers from overseas, lured by the diamond and goldmining industries, brought their craft-union traditions with them. But within the context of a colonial conquest society, craft-based exclusion became transformed into racial exclusion, a practice that continued into the industrial era. Within six months of its formation, the CPSA was jolted by the realities of South Africa's racial politics. The 1922 Rand Revolt, an uprising of white working-class people that began as a strike of white

65. Ibid., p. 76 .

66. McDermott and Agnew, The Comintern, pp. 44-46, quotes 46; Henry Pelling, The British Communist Party: A Historical Profile (London, I958), pp. 2 I-22.

67. "Theses on the Bolshevisation of Communist Parties, adopted by the Fifth ECCI Plenum, April 1925", in McDermott and Agnew, The Comintern, pp. 232-233, quotes 233. 
mineworkers, starkly exposed the racial divisions of South Africa's labour force. A now notorious banner held aloft by white male workers and their wives proclaimed "Workers of the World Fight and Unite for a White SA" ${ }^{6} 8$

The 1922 Rand Revolt had a deeply traumatizing impact on communists. Sidney Bunting, an Oxford-educated lawyer, and a founding member of the CPSA, tried to straddle and unite both black and white sections of the labour movement. This aim flowed from his belief that discord across the colour line was the main obstacle to the overthrow of capitalism. Bunting saw the struggle for equal rights as a pragmatic step to achieving working-class solidarity across the colour line: "inasmuch as inequality is a bar to cooperation", he argued in October 1922, "an attempt must be made before, not after, the revolution to mitigate it so far as necessary to facilitate cooperation". ${ }^{69}$ Bunting's initial optimism that the state's brutal squashing of the Rand Revolt would induce white workers to seek solidarity with black workers was misguided. ${ }^{\circ}$ White racism increased in the next few years. White workers, reported Bunting to the Comintern, still had a "damned nigger" attitude. ${ }^{7 \mathrm{r}}$

Proponents of work amongst blacks - chiefly Bunting, a few Young Communist League members from Johannesburg, and some of the Cape Town branch - had been marginalized by the Rand Revolt and the state's brutal reaction. Black leaders had been hostile to white miners in the Rand Revolt. The views of Dr Abdurahman, President of the APO, who claimed that "the greatest exploiters of coloured labour on the Rand are the white workers, and their 'solidarity' has resulted in our being kept down at unskilled work", was not atypical. ${ }^{2}$ But the trauma of the Rand Revolt was still vividly felt by Johannesburg communists, and articles about the Revolt and tributes to those who had died - "class-war heroes" - figured prominently in March 1923, the first anniversary of the strike's defeat.73

At its Second Congress, held in Johannesburg in April 1923, the CPSA adopted the Comintern's united-front policy, and voted to apply for affiliation to the Labour Party. ${ }^{74}$ Despite the Labour Party's subsequent

68. Drew, Discordant Comrades, pp. I3-16, 20-57, 59-64.

69. S.P. Bunting, "The 'Colonial' Labour Front, 23 October I 922 ", in Allison Drew (ed.), South Africa's Radical Tradition: A Documentary History, vol. I (Cape Town [etc.], I996), pp. 5 I - 54, 53. 70. S.P. Bunting, "The Rand Revolt: Causes and Effects", R.K. Cope Papers, A953/6a, Historical Papers Library, University of the Witwaterstand, p. 23.

7I. Letter from S.P. Bunting to I. Amter, Communist International, 24 November 1923, RGASPI, 495.64.I4; Eddie Roux and Win Roux, Rebel Pity: The Life of Eddie Roux (London, I970), p. 26.

72. Quoted in S.P. Bunting, "The Bitter Cry of Outcast Africa", International, I 3 April I923, p. 3 .

73. International, 9 March I923, pp. I-2.

74. CPSA Second National Congress, 28 and 29 April I923: Agenda, Delegates to Congress, and Minutes, RGASPI, 495.64.I6. 
rejection of communist overtures, ${ }^{75}$ the CPSA supported the electoral pact of the National and Labour Parties against Jan Smut's brutally antiworking-class South African Party. "Vote Pact", urged a CPSA manifesto which appeared in May 1924, about a month before the election, "not for the sake of the 'Pact' but [...] as a step towards WORKERS' CONTROL OF THE WHOLE MEANS OF PRODUCTION and SELF-DETERMINATION IN A WORKERS’ REPUBLIC!"76

The Party's stance towards black organizations during this period was equivocal: while believing the ANC to be dominated by "instruments of the ruling class", it was unsure whether the ICU was a "fit and proper body" to deal with its own agenda. ${ }^{77}$ The huge educational and skills differential between blacks and whites meant that the Party found it very difficult to find and recruit African organizers and this, from Bunting's point of view, impeded the Party's organizing efforts. "But the best propaganda", he informed the Comintern, "will be not by Communists as such, but a case in which in a strike of natives the white workers openly stand by them." ${ }^{8}$ However, it became clear that the new Pact government was just as racist as its predecessor, dousing hopes that white labour organizations would reach out to blacks. ${ }^{79}$ The entrenched racism of white trade unions strengthened the hand of those wishing to give more attention to the organization of black workers. The contest came to a head at the Party's Third Congress, held in Johannesburg in December I 924.

The CPSA's turn to black labour in the mid-I 920 s was facilitated by the entry of a number of young people into the socialist movement who were concerned with organizing those outside the traditional orbit of trade unions: black and women workers. The Young Communist League was pivotal in the Party's turn towards black labour, despite its all-white, and mostly male, membership; it was, perhaps, less imprisoned within the routines and outlook of organized white workers. Its members, workers, clerks, and shop assistants, and a few students, became swept up in the waves of meetings and demonstrations during the Rand Revolt and in the campaign to free the Rand strikers after the revolt. By early 1924, two Young Communist League members, Willie Kalk and Eddie Roux, convinced the league to admit blacks. The league's turn to blacks dovetailed with the Comintern's growing interest in the Negro question;

75. "Affiliation with the LP”, International, 25 May i923, p. 2; "Keep out the Communists: SA Labour Party Baulks Again", and "Communist Affiliation: Letter from the Labour Party”, both in International, 27 July 1923, pp. 2 and 4 respectively. See also R.K. Cope, Comrade Bill: The Life and Times of W.H. Andrews, Workers' Leader (Cape Town, 1944), pp. 286-287.

76. "Communist Party, SA: Election Manifesto", International, r6 May I923, pp. 6-7.

77. “An 'African Labour Federation", International, i I January i924, p. 3.

78. S.P. Bunting, to I. Amter, Communist International, 24 November 1923, RGASPI, 495.64.I 4 .

79. "In Quest of Reason", International, 26 October 1923, p. 3. 
Roux reported the situation to the Young Communist International, which sealed the matter by endorsing the proposal to recruit blacks. ${ }^{80}$

The debate in the Young Communist League parallelled the contest within the CPSA, which culminated at the Party's Third Congress. "[I]f our Conference accomplishes no more than to remove mutual aloofness on the subject of native affairs, it will have justified itself", argued Bunting. The entire labour movement, he went on, "is paralysed and stultified by its failure to tackle its native question". The CPSA "should strenuously resist any tendency to a similar paralysis". The Congress resolved not to apply for affiliation to the Labour Party but instead to work towards a united front. Crucially, the Congress decided "that the overthrow of capitalism can only be achieved through the joint endeavours of all the workers", and it "urge[d] all branches to help to the utmost all the attempts of the native workers to organise industrially" ${ }^{81}$ Its programme demanded the abolition of the indentured labour and pass systems and the repeal of restrictions on the right to strike; "equal pay for equal work", regardless of colour, sex, or age; the nationalization of mines and banks; the expropriation of big estates in favour of landless workers and the provision of land for Africans; and votes for women. The Congress was a victory for those seeking greater attention to black workers. ${ }^{82}$

The Party's decision in December 1924 actively to recruit black workers led to significant changes. Crucially, Bunting used the organizational reforms mandated by Bolshevization as a mechanism to launch and to legitimize the turn to black workers. The year 1925 was difficult for the CPSA as it introduced both agendas. Discussions about the reorganization began in force in the second half of the year. Two British communists, Jimmy and Violet Shields, spent several years in South Africa, helping the Party to introduce the new policy. The proposed organizational changes were initially limited to the regularization of agendas for monthly meetings and the setting up of specified duties and study classes for members, although over the next year changes were stepped up..$^{83}$

Problems with the new orientation were already apparent by the CPSA's Fourth National Conference in Cape Town in December I925. The shift towards black workers inevitably antagonized white workers,

80. Roux and Roux, Rebel Pity, pp. 24-28, 30-37; "Young Communist Notes", International, 9 May 1924, p. 8; "Young Communist Notes", International, i 8 July 1924, p. 8; "Our Social Composition", Young Worker, II, I, January 1924, p. 4.

8I. CPSA Third Congress, Johannesburg, 27-30 December 1924, quotes pp. I4 and 20, RGASPI, 495.64.33. See also Roux, S.P. Bunting: A Political Biography [1944] (Bellville, 1993), pp. 104-I06.

82. "Draft Communist Party Programme Adopted by the Party Conference on December 30 , 1924, for Submission to the Branches", in Bunting, South African Communists Speak, pp. 80-84. 83. CPSA Central Executive Committee Minutes, 6 August and 20 August 1925, RGASPI, 495.64.42; Letter from E.S. Sachs to General Secretary, CPSA, 2 I November 1925, RGASPI, 495.64.40; CPSA Central Executive Meeting Minutes, 22 April 1926, RGASPI, 495.64.53. 
and alienated many of the Party's white followers and active members. There was a high turnover both in the general membership and on the Central Executive. ${ }^{84}$ But these difficulties should not deter a true Bolshevik Party, Bunting argued. "Bolshevization", he exhorted, "consists in espousing the cause of the native workers. The SALP has no future although the 'white S. Africa' slogan is still popular with whites on the Rand". ${ }^{85}$ The debate at the Fourth National Conference reflected a diversity of views on the matter. Nonetheless, Bunting was emphatic. "It still remains that many of our members are reluctant in this matter - our most Bolshevik work", observed Bunting. "If carrying on this work offends the white trade unionists we should still go ahead with it." 86

The Party launched a series of activities geared to attract black workers: night school, trade-union work, meetings, and public gatherings. Until I925, William Thibedi had been the Party's only African member. By I928, it claimed about I,600 African members out of approximately I,750, and in the middle to late I920s it recruited a number of significant black leaders. Many of those who rose up the hierarchy came from a background where education was valued, and a number were teachers. However, the majority of blacks who joined the Party, particularly in the Transvaal, were workers from small semirural locations. ${ }^{87}$ Thibedi, the son of a Wesleyan minister, taught in a Wesleyan school in Johannesburg. He was, Roux later wrote, "a genius at getting people together, whether workers in a particular industry, women, location residents, or whatever was needed at the moment" ${ }^{88}$ In 1925 , the CPSA started a night school under his direction. This attracted forty students in its first year. Initially, classes were held by candlelight at an African church in Ferreirastown. The programme was heavy going, covering Bukharin's and Preobachansky's ABC of Communism and Bukharin's Programme of the World Revolution. The school became extremely successful at training African cadres; a number of African recruits who became influential activists gained an education in the night school. ${ }^{89}$

The CPSA also began using its paper more strategically, despite the fact

84. Fourth National Conference of the Communist Party of South Africa held at 145 Long Street, Cape Town, on December 26-28 I925, RGASPI, 495.64.43; see also Cape Town branch report to Central Executive Committee for I925, RGASPI, 495.64.45.

85. Fourth National Conference of the Communist Party of South Africa, p. I7.

86. Ibid.

87. Roux, Time Longer than Rope [1948], 2nd edn (Madison, WI, 1964), pp. 2 I4-2 16; Roux, S.P. Bunting, pp. 52, I26; Johns, Raising the Red Flag, p. I26.

88. Roux, S.P. Bunting, p. I16; Robert Edgar, interview with Edwin Mofutsanyana, Roma, Lesotho, July i 98 I, pp. 20-21.

89. Roux, S.P. Bunting, pp. I07-I08, I I 3-I I 4; Roux and Roux, Rebel Pity, pp. 68, 92, I 28, I44; Roux, Time Longer than Rope, pp. 132, 225; Fourth National Conference of the Communist Party of South Africa, p. 37. 
that its printing press was suffering severe financial difficulties..$^{\circ}$ In 1926 , the name of the Party's paper was changed from the International to the South African Worker, its masthead now bearing the figures of a shirtless black miner and a skilled white worker. The paper gave more attention to issues affecting black workers and began running educational articles. The 27 August issue announced that "A Communist Primer for South Africa", was to be serialized in the paper to replace the Eurocentric $A B C$ of Communism. ${ }^{\text {I }}$ In February 1926, the Central Executive Committee had discussed the possibility of publishing African-language articles, and decided that Thibedi "should submit an article as an experiment"; by 1928 about two to three pages per issue were written in African languages. ${ }^{92}$

Party activists also turned their attention to the all-black ICU. In 1923 this began to spread "like a veld fire" across the country, setting up branches in the coastal towns of Port Elizabeth and East London, then in the rural areas, where it organized blacks living on white farms who were at risk of losing their access to land. Because of its success, the ICU began attracting the attention of a number of black leaders and activists who had previously remained aloof. 93 The ICU showed the possibility of a radical mass mobilization - an achievement which necessitated a response from the CPSA. ${ }^{94}$ By 1926, five black communists were on the ICU's National Council, and Thibedi was an ICU shop steward and organizer. By the end of the year, though, the communists' honeymoon with the ICU was over: the ICU stipulated that communists could not remain on the executive.95 While this certainly hurt the CPSA's ability to build a mass base, the Party nonetheless retained some support at local ICU branch level. Through the black activists that had joined the CPSA in the mid- and late I920s, and that rose through its ranks, the Party was able to maintain its demographic representation.

\section{BOLSHEVIZATION, POLITICAL REPRESSION, AND NATIONAL LIBERATION IN ALGERIA}

The difficulties faced by the Communist Party in Algeria in recruiting Algerian members are in stark contrast with the South African experience.

90. Central Executive Committee Minutes, 22 October 1924, RGASPI, 495.64.42; S.P. Bunting to Secretary, ECCI, 3 November 1926, RGASPI, 495.64.48.

9r. "A Communist Primer for South Africa", South African Worker, 27 August 1926, p. 3.

92. CPSA Central Executive Committee Minutes, 4 February 1926, RGASPI, 495.64.53.

93. Clements Kadalie, My Life and the ICU: The Autobiography of a Black Trade Unionist in South Africa, Stanley Trapido (ed.) (London, 1970), pp. 19, 8 I; P.L. Wickens, The Industrial and Commercial Workers' Union of Africa (Cape Town, I978), p. 93.

94. Kadalie, My Life and the ICU, pp. 72-73; CPSA Central Executive Minutes, 9 September 1926, RGASPI, 495.64.53.

95. "Obey Orders", Workers' Herald, I4 September 1926, p. 2; CPSA Central Executive Committee Minutes, 2I June 1926, RGASPI, 495.64.53. 
In South Africa, white labour had revived sufficiently, following the Rand Revolt, to ensure the electoral victory of the Pact government, even though this was at the cost of coopting the white labour movement into the state apparatus, and the ICU was sweeping the country. By contrast, the year I 925 was a low for the working-class movement in Algeria, after the peak represented by the I919-1920 strike wave, and a high point for capital, particularly agrarian capital, due to the increase in the price of wheat. But Bolshevization in Algeria became intertwined with two political issues that were absent from the South African landscape at the same time. First was the Rif war, which sharply intensified repression against Communists in Algeria. Second was the issue of national liberation and the call for independence.

Bolshevization was introduced to the French Communist Party in September 1924. The policy undoubtedly had its critics, but it also had significant proponents, first and foremost the Young Communists who climbed the Party hierarchy as a result of their support. There were also supporters amongst the few Party members who were concerned with colonial questions. As was the case in South Africa, some North African communists saw the organizational changes mandated by Bolshevization as a means to reorient the local SFIC towards Algerians. The old, allegedly social-democratic, methods were equated with colonialist attitudes. In June 1924, for instance, Ali Abdelaziz Menouer, an Algerian member of the SFIC's Comité d'études coloniales, wrote to a Comrade Kolaroff in Moscow complaining of the SFIC's lack of interest in the colonial question - "Jusqu'au commencement I924, le parti n'avait rien fait pour organiser les travailleurs coloniaux" 96 - of its foot-dragging on the education of comrades from colonized areas, and of the commission's lack of representation at the Fifth Congress. He also complained about the centre's decision to send Comrade Ferrand of Sidi-bel-Abbes as the Algerian delegate. Comrade Ferrand was active and intelligent, wrote Ali Menouer, but it was feared that he would present only his point of view, based on a European understanding, and reflective of the line followed by Europeans in Algeria, which was not always very communist. However, Menouer added, those supporting greater emphasis on the colonial question would be very pleased if the Comintern's directives and the proposed methods of action presented at its Fifth Congress were implemented. 97

The French Communist Party began paying greater attention to its Algerian region following its adoption of the Bolshevization policy. In

96. Aziz [Ali Menouer], Rapport sur le travail parmi les coloniaux en France, 6 pp., handwritten, n.d. [1924], RGASPI, 517.1.I85. Ali Menouer used the pseudonyms Ali, Aziz, and "El Djazairi" [the Algerian].

97. Aziz [Ali Menouer] to Camarade Kolaroff, i7 June i924, handwritten, 3 pp., PCF file 70 , quotes p. I. 
September 1924 the Comité d'études coloniales was reorganized as the Commission coloniale centrale. $9^{8}$ Jacques Doriot, a Paris-based communist who specialized in anticolonial agitation, and found ready favour in Moscow due to his loyal support of Comintern policies, gave some indication of Paris's approach. Heretofore, the SFIC had been remiss in its anticolonial work, he indicated in December 1924, and this made the present efforts more difficult. Nonetheless, the Party had begun to explain the new policy to its Algerian region. However, the state of mind that had characterized the local communists had not entirely disappeared, he noted, and diligent work would be necessary to create federations able to manoeuvre in the complicated environments of Algeria and Tunisia. ${ }^{99}$

In order to facilitate centralization, a decision was made at the SFIC's fourth national congress in Clichy in January ig2s to fuse the three Algerian federations. ${ }^{100}$ The fusion was formalized at a congress in Algiers on 22 March I925, accompanied by expulsions. ${ }^{\text {IOI }}$ It also saw the rise of a new personality, Pierre Biboulet, Secretary of the Algiers region, who played a large role in the fusion and in the early implementation of Bolshevization; it was not a task, evidently, that made him popular amongst his comrades. ${ }^{102}$ Along with the move toward centralization went the adoption of a more emphatic approach to indigenization. The Algiers congress agreed to the new orientation, acknowledging that the indigenous masses had to be wakened both to their national consciousness and to the class struggle, and that this "must be the principal task of the Communist Party in Algeria" - a striking parallel with the CPSA's Third Congress of December $1924 .{ }^{103}$

Although communists in Algeria had discussed the possibility of running both European and Algerian candidates in the municipal elections of May 1925, Bolshevization gave new impetus to this. The campaign generated mass enthusiasm amongst the Algerian population - but also unleashed a wave of government repression. The SFIC had already received extremely positive feedback, both from Algerians in France and in Algeria, following its decision to run Hadj Ali Abdelkader, a Paris-based Algerian and a naturalized French citizen, as a candidate in local Paris elections. ${ }^{104}$ In Algeria, the local SFIC put forward a European list and an

98. Pierre Durand, Cette mystérieuse section coloniale: le PCF et les colonies (1920-1962) (Paris, I986), p. 48.

99. G. Doriot to "Cher camarades", i 8 December 1924, PCF file 70.

ı००. P. Biboulet, Rapport sur la situation politique en Algérie, I7 October 1925, I0 pp., typed, PCF file I 20, p. 4 .

Iог. "Congres de fusion", Lutte Sociale, i 3 February i925.

102. "Pierre Biboulet", in Dictionnaire Biographique du mouvement ouvrier français, part 4, 1914-1939, vol. i9 (Paris, I983), p. Is I.

I03. Biboulet, Rapport sur la situation politique, p. 4.

I04. Aziz to Camarade Kolaroff, p. 2; "40.000 ouvriers parisiens ont voté pour le Communiste Hadjali Abdelkader”, La Caserne, May-June 1924, pp. 6-7, RGASPI, 5I7.I.I 85. 
Algerian list under its "workers and peasants bloc". The Algerian list was headed, symbolically, by Emir Khaled and by Mahmoud ben Lekhal, an exiled Algerian communist who had been very active in the SFIC's campaign against the occupation of the Ruhr; it was a move that was highly successful for the Party in terms of arousing local Algerian interest. ${ }^{\text {Io }}$

The electoral activity attracted new members. The majority of new recruits were Algerians, attracted by the new orientation, which gave greater attention to Point 8 of the Comintern's Twenty-one Points. The new orientation was reflected in Lutte Sociale, which, since the fusion conference, was trying to attract a francophone Algerian readership, with greater coverage of Algerian issues and slightly larger and more readable headlines. Some of the new members were Europeans, attracted by the electoral campaign. But, in the aftermath of the elections, many new members left. The sudden exodus precipitated a feeling of crisis amongst local communists. Against this backdrop, the Party was ill-prepared for an onslaught of repression from the state.

The implementation of Bolshevization in Algeria coincided with, and was justified by, the SFIC's agitation against the Rif war in Morocco. This gave Bolshevization in Algeria a particular twist that contrasted markedly with the South African experience. The immediate causes of the Rif war dated to I919, when Spain decided to conquer and subdue the Rif people. Its attempt failed; in July I92 I Abd el-Krim defeated the Spanish army in Morocco, and in late January 1923 declared the Republic of Rif. In midI924, following a coup in September 1923, the Spanish withdrew from the Rif. In May I 924, I 2,000 French troops were sent to the Rif; these were attacked by Abd el-Krim the next month. But two years later, in May I926, faced with a coalition of French and Spanish forces, Abd el-Krim surrendered and was exiled to Reunion. ${ }^{106}$

The Rif war gave the French Communist Party an opportunity to put Point 8 of the Twenty-one Points into practice, and it conducted a vigorous campaign against militarism and against the French army in Morocco - in sharp contrast to the Socialist Party's ambiguous stance. ${ }^{107}$ This antiwar campaign attracted and was sustained by the efforts of Young

I05. "Election municipales du 3 Mai i925", Lutte Sociale, i7 April I925; "Elections municipales du 3 Mai 1925", Lutte Sociale, 24 April 1925; Lutte Sociale, Edition spéciale, May 1925; "Aux électeur indigènes", Lutte Sociale, 8 May 1925 ; “L’Emir KHALED est ELU”, Lutte Sociale, is May i925. See also Abderrahim Taleb Bendiab, "La pénétration des idées et l'implantation communiste en Algérie dans les années 1920", in René Gallissot (ed.), Mouvement Ouvrier, Communisme et Nationalisme dans le monde Arabe, Cahiers du "Mouvement Social” no. 3 (Paris, I978), pp. I27-I46, esp. I35, and Alleg, La Guerre d'Algérie, vol. I, p. 201.

I06. William A. Hoisington, Jr, Lyautey and the French Conquest of Morocco (New York, 1995), pp. 185-204; Koulakssis, Le parti socialiste, pp. I89-193. Arturo Barea discusses the Spanish war in the Rif in his autobiography, The Track (London, n.d.).

107. Zakya Daoud, Abdelkrim: une épopée d'or et de sang (Paris, 1999), pp. 207-235; Koulakssis, Le parti socialiste, pp. 193-199. 
Communists, both in France and in Algeria. Many of the leading Young Communists in mid-I920s Algeria were Europeans, but a number of Algerians joined around this time. Benali Boukort, for example, who became Secretary-General of the Algerian Communist Party in 1939, joined the Young Communists in 1924. ${ }^{108}$ The repression to which communists in Algeria were subjected, as a result of their direct confrontation with state policy, provided the rationale for a more centralized political approach offered by Bolshevization. As Ageron noted: "Le bolchévisation du parti s'accomplit en Algérie comme en France à la faveur de la guerre du Rif."

From the mid-I 920s, the SFIC in Algeria was hit by a wave of repression that appears to have been far greater - when measured, for example, by numbers and duration of prison sentences - than that faced by the CPSA in the same period. The CPSA had faced state repression during and immediately following the I922 Rand Revolt, but this had subsequently eased. South African communists had relative freedom of movement in the I920s; prison sentences were generally for two to three months, and skilful lawyers could often help their clients avoid prison altogether. ${ }^{\text {IO }}$ By contrast, in 1924, the SFIC's stance on the Rif war in Morocco brought it into direct confrontation with the French state - and the consequences were very heavy indeed for communists in Algeria. A portent of things to come was the arrest of Pierre Biboulet in June I925, a month in which the Party had directed its energies to a public campaign against the war. The following month, July I925, the SFIC sent three representatives from Paris - Henri Lozeray, Victor-Noël Arrighi, and Jean-Baptiste Aucouterier - to the Algerian region to campaign against the Rif war. They were arrested on arrival in Algiers and sentenced in September to two years in Barberousse Prison. ${ }^{\text {II }}$ Arrests of other local communists soon followed. In August eleven comrades were detained at Barberousse prison, where others were already incarcerated. A number of these were prominent in the local Young Communist League.

That same month Paul Henriet was sent to pick up the thread. Keen to impress Paris headquarters, Henriet reported that he had guided local communists in Blida - mainly European artisans - in their propaganda work in order to ensure Algerian attendance at an upcoming congress. As was the case with South Africa, the sheer physical difficulty of communication in a country as large as Algeria, with its relatively undeveloped infrastructure, made centralization an ambitious - if not impossible - goal.

108. Benali Boukort, Le souffle du Dabra (Algiers, I986), p. 30.

ı09. Ageron, Histoire de l'Algérie Contemporaine, p. 380.

I I0. Roux, S.P. Bunting. Sidney Bunting was often successful in the r 920 in getting charges against communists dropped.

I I I. "Henri Rudolphe Lozeray", in Dictionnaire Biographique du Mouvement ouvrier français, part 4, I914-1939, vol. 35 (Paris, 1989), p. 92. 
Based mainly in Algiers, Henriet informed Paris that he planned to spend a week in Oran: "I am going to study the situation there, as here people know practically nothing about Oran. As far as Constantine is concerned, our letters have gone unanswered for two months." II2

The country's great size and its limited infrastructure were certainly impediments to communication, making national distribution of the Party's paper, Lutte Sociale, all the more important. But the paper was particularly hard hit by the repression, subjected to frequent seizures that had negative repercussions, both financially and for the Party's ability to disseminate its views. The paper was badly in debt, and Père Targe, the printer, was extremely angry. Targe felt that the paper's antiwar propaganda made it a continual target of the regime's wrath, and argued that the paper should focus on legitimate electoral activity instead. It was vital, Henriet advised Paris, that the centre subsidize Lutte Sociale. The paper was "the only means to reach the natives in the interior and elsewhere", he argued, "because the repression already unleashed and the repression to fear has made many comrades go into their shell". ${ }^{113}$ Repressive laws intimidated people both from renting meeting space to communists and from attending their meetings. Attendance dropped. "The last meetings had proved that natives and Europeans would not attend", Henriet observed, necessitating private meetings. They had to be careful to ensure that their most recent friends were not subjected to repression. His words - "Nous ne sommes plus en France" - merely underscored the contradictory nature of the Algerian situation. ${ }^{\text {I } 4}$

Over the next several years, a series of leading activists were imprisoned, often for periods of two years, due to antiwar activities. This made it virtually impossible to organize and coordinate activities and devastated morale. But Bolshevization in Algeria not only differed from the South African experience in terms of the level of repression. If Bolshevization in South Africa became intertwined with the Party's reorientation towards black labour - a reorientation that nonetheless clearly accepted the primacy of class struggle and the state's territorial boundaries - in Algeria it became intertwined with debates about national liberation and independence. The idea of a national liberation movement that raised the possibility of independence from France was clearly much more difficult for communists in the SFIC than the notion of black and white workingclass unity was for South African communists. Tensions around this issue were apparent in late 1925 , and mounted to a destructive level over the next few years.

I I 2. Rapport de Henriet, Algiers, I September I925, 3 pp. typed, p. 3, PCF file I 20; translated from the French.

I I 3 Ibid., pp. I-2.

I I 4. Ibid., p. 2. 
The Comintern's call to build a national liberation movement in Algeria met with strong resistance from local communists. Many argued that the call for national liberation was premature; instead they emphasized the struggle for equality and for working-class unity within the existing colonial framework. Ironically, Henriet came to share this view. He had been particularly impressed by Henri Schiavo, a trade-unionist from Blida who did not think it was possible to build a national movement. Schiavo would be an ideal leader for the local communists, Henriet wrote Paris. He had created a magnificent union of Europeans and Algerians and spoke some Arabic. He was, Henriet thought, "l'homme du moment". What Algerians wanted, Henriet informed Paris, was equal rights with Europeans. They understood that conditions imposed a class struggle rather than a struggle for independence, which would lead nowhere. ${ }^{\text {II }}$

But Pierre Biboulet was one who believed that the French Communist Party should promote a national struggle for independence. Biboulet was severely critical of the local Party's delay in recruiting Algerians. Even up to the legislative elections of May i 924, he claimed, the Party had failed to take a position on "la question indigène" for fear of alienating the "petits colons". This delay he attributed both to a social-democratic outlook, closer in spirit to the Second rather than the Third International, and to racial prejudice, which, he stressed, existed even among communists. ${ }^{\mathrm{I} 6}$ In Biboulet's view, the repression against the Party was as much a response to the Communist Party's joint European-Algerian electoral campaign as to the Party's antiwar campaign; the possibility of fraternity between Europeans and Algerians was a greater threat to the state than the Party's antiwar campaign. Biboulet believed that the Algerian majority nurtured the hope of independence. He wrote to Paris,

How can one doubt it $[\ldots]$ when we see the passionate interest with which the Algerian natives follow the events of Rif and of Syria? In the most remote douarts, in cities and in the countryside, amongst Arabs and amongst Kabyles, amongst the uneducated as well as the intellectuals, everyone is avid for news. ${ }^{\mathrm{II} 7}$

At a meeting in Blida, Biboulet wrote, an Algerian interrupted to call for "a state that is independent of all European tutelage". ${ }^{\text {I18 }}$

Tensions over this issue increased the following year. In February I926, the Algerian federation held its annual conference. A report in Lutte Sociale underlined the need for alliances between the working class and national movements. It urged European communists to surmount their attitude of racial superiority vis-a-vis Algerians, an attitude that was

I I . Ibid.

I 6. Biboulet, Rapport sur la situation politique, p. 3.

I 17. Ibid., p. 6, translated from the French.

I 18. Ibid., p. 7, translated from the French. 
deliberately fostered, it argued, by the imperialist bourgeoisie in order to facilitate its colonial policies. Organizing for national liberation was one step in the struggle against French imperialism, and even if this effort led only to a national revolution, this outcome would help to expose class antagonisms. ${ }^{119}$ Yet this view was not uniformly held, and political differences did not necessarily correspond to nationality. Amar, a comrade from Algiers, argued that the demand for "Indépendance de l'Algérie" did not correspond to the actual situation. Instead, the Party should develop a policy appropriate to the actual conditions rather than launching slogans that would not be understood either by the Algerian or the European masses. In his view, the Party should organize Algerians as workers in trade unions, develop their class-consciousness and fight against the indigénat. Nonetheless, the conference decided by a vote of twenty-eight for and six against, with five abstentions, to promote the slogan of independence. ${ }^{\mathrm{I} 20}$

This position was reinforced at the French Communist Party's fifth national congress in Lille in June 1926, which underlined the need to address the colonial question and to contest the influence of the Socialist Party, whose position on colonialism was seen as counterrevolutionary. ${ }^{\text {I2I }}$ Nonetheless, discord about the call for independence continued throughout 1926 and beyond. Like the Communist Party, the Young Communist League, which had been heavily hit by repression, was divided over the issue. ${ }^{\mathrm{I} 22}$ Its political secretary, Ayache, argued that since the YCL was not known throughout Algeria, it should first penetrate the masses through regular activity, calling for fraternization between European and Algerian soldiers without adding the premature demand for independence, which would only exacerbate the repression against Young Communists. Lutte Sociale had already been seized for much less radical slogans, he pointed out. ${ }^{\mathrm{I} 23}$ Animosities over this issue escalated over the next several years. The disagreements became increasingly hostile and personalized, and were accompanied by expulsions; communists in Algeria sought the assistance of Party headquarters in Paris against each other. But these disagreements took place when the Communist Party in Algeria was already devastated by repression and virtually inactive in some areas. They compounded the tiny Party's problems further.

I I9. "En vue de la Conférence: ce que doit-être notre politique Coloniale en Algérie", Lutte Sociale, I9 February 1926.

I 20. "Le rayon d'Alger adopte à une forte majorité les thèses presentées par le Comité central", Lutte Sociale, 26 February I926.

I 2 I. Sous-Commission Nord Africaine, Séance du 28 Juillet I926, RGASPI 5I7.I.409, p. I.

I22. Letter to Camarades, Setif, 4 October [1926], RGASPI 517.1.456.

I23. Ayache to Camarades du CC, 20 October 1926, RGASPI 517.I.456. 


\section{CONCLUSION}

Despite the French Communist Party's growing recognition of the need to work amongst and recruit Algerians, there was great variation in the way that communists in Algeria interpreted this agenda. Yet, there were individuals with a will to actively recruit Algerians. How then do we explain the differential success rates in Algeria and South Africa with regards to indigenization? In broad strokes, Algeria and South Africa show striking parallels in their political economies. Yet, they also show striking contrasts in their patterns of proletarianization and urbanization, notably, Algeria's displaced proletariat and South Africa's migrant labour force. Classical Marxist theory, on which these early communists largely based their analyses, assumes the primacy of the urban working class in social change. Whatever the difficulties faced by South African communists in this regard, the conditions facing communists in Algeria were more difficult. Their country was less urbanized than South Africa at comparable points in time, and a critical section of the Algerian working class was in France. The contrasting patterns of proletarianization and urbanization in these two cases posed constraints both on the immediate prospects for organizational development in the respective working classes and, in turn, on the perceptions and attitudes of local communists.

South Africa's lack of a well-rooted pre-existing socialist or socialdemocratic tradition may well have made the tasks of early communists very difficult, and also made them more vulnerable to the Comintern's influence. Nonetheless, the two revolutionary traditions inherited by communists in Algeria - that of France and that of the Bolsheviks - were a heavy burden. The two traditions loomed large in the pages of Lutte Sociale, which were weighed down by their influence, leaving little space for Algerian issues. In terms of local content and of creative editorial experimentation to attract the urban indigenous working class, Lutte Sociale lagged behind South African Worker in those years. The existence of a social-democratic alternative in the form of the Socialist Party also presented difficulties for communist organizers in Algeria. Despite its minute size, the Socialist Party presented a credible left-wing alternative for European workers in Algeria that could also lay claim to the French revolutionary tradition.

The Comintern's relationships with communists in Algeria and South Africa also differed markedly, posing serious challenges for the unidimensional centre-periphery framework that has dominated communist studies. The Comintern prioritized those countries and regions that it believed to be of international geopolitical significance. This necessarily included the French Communist Party, whose relationship with the Comintern was frequently tense. The Comintern intervened in Algeria far earlier than it did in South Africa, and the impact of its policies was felt far earlier. 
Although views similar to those expressed in the Sidi-bel-Abbes thesis could be found amongst early white South African communists, the Comintern made an example of the former in no small part to criticize the French Communist Party. Moreover, the Comintern's increasing emphasis on assisting national liberation struggles was felt first in Algeria, coinciding with the first few years of Bolshevization and with an intensification of state repression against Communists. The CPSA, by contrast, confronted the issue of national liberation in 1928, after the Party had made significant progress with indigenization; even then, national liberation was conceived in terms of full equality and never in terms of transformation of the state's territorial boundaries. ${ }^{\mathrm{I} 24}$

Communist activity in Algeria in the mid-I920s took place during a repressive climate; in turn, it undoubtedly led to an intensification of repression. By all indications, the onslaught of repression against communists in Algeria was greater than in South Africa - reflecting both French colonial control and the geopolitics of the Rif war - and impeded the growth of a tiny party. Certainly, the different degrees of repression experienced by communist activists in Algeria and South Africa goes some way in explaining the contrasts in the abilities of the two parties to indigenize. In sum, each of the four variables was experienced differently by communists in the two countries. The cumulative weight of the variables in the Algerian case helps to explain why, in the I920s, communist activity - including the Communist Party's ability to indigenize - was far more difficult in Algeria than South Africa.

An evaluation of communist experiences by reference to a multivariable and comparative approach highlights the limitations of the centreperiphery model that characterized communist studies for many decades, especially during the twentieth century's long Cold War. In this case, the intensity of the problems faced by communists in Algeria can only be understood by comparison with other communist experiences. Moreover, the relative difficulties that the Communist Party in Algeria faced in recruiting Algerian members may, in turn, provide insight into its ambiguous relationship with the national liberation movement over the ensuing decades - again in notable contrast to the South African experience. This suggests that the history of international communism can be understood as sequences of policies that, because they are applied in different national contexts with cumulative effects, produce increasingly divergent outcomes in those countries.

I 24. For the CPSA's reactions to the Comintern's pressure to deal with national liberation, see Drew, Discordant Comrades, pp. 94-I I I. 